Kredo 3 (2020)
KREDO: Jurnal Ilmiah Bahasa dan Sastra
Terakreditasi Sinta 4 berdasarkan Keputusan Direktorat
Jenderal Penguatan Riset dan Pengembangan,
Kementerian Riset, Teknologi dan Pendidikan Tinggi
Republik Indonesia
Nomor: 23/E/KPT/2019. 08 Agustus 2019
https://jurnal.umk.ac.id/index.php/kredo/index

\title{
PENERAPAN MODEL CONTEXTUAL TEACHING AND LEARNING TERHADAP PENINGKATKAN KETERAMPILAN MENULIS PENDAPAT PRIBADI
}

\author{
Eva Maela Sofia ${ }^{1}$, Irfai Fathurohman ${ }^{2}$ Imaniar Purbasari $^{3}$ \\ evamaelasofia@gmail.com ${ }^{1}$,irfai.fathurohman@umk.ac.id ${ }^{2}$, \\ imaniar.pubasari@umk.ac.id ${ }^{3}$
}

Program Studi Pendidikan Guru Sekolah Dasar ${ }^{1,3}$, Program Studi Pendidikan Bahasa dan Sastra Indonesia ${ }^{2}$, Fakultas Keguruan dan Ilmu Pendidikan Universitas Muria Kudus, Indonesia

Info Artikel
Sejarah Artikel
Diterima 29 April
2020
Disetujui 15 Mei
2020
Dipublikasikan 20
Mei 2020
Keywords
contextual teaching
and learning,
personal openion
writing skills
Kata Kunci
$\begin{aligned} & \text { contextual teaching } \\ & \text { and learning, } \\ & \text { keterampilan menulis } \\ & \text { pendapat pribadi }\end{aligned}$

\section{:}

$:$ using the Contextual Teaching and Learning (CTL) learning model approach. This study was conducted in two cycles with 4 meetings of 35 students in grade IV SD 2 Hadipolo of the 2019/2020 academic year and this study used the Classroom Action Research. Data collection techniques through observation, testing, and documentation. The results of the study of personal opinion writing skills using the Contextual Teaching and Learning model showed that there was an increase in each meeting. The skills of students writing personal opinions at the first meeting gained 58\% and at the second meeting scored $61 \%$ with an average percentage of $60 \%$ and qualified enough. At the third meeting got $73 \%$ and the fourth meeting got $82 \%$ with an average percentage of $78 \%$ good qualifications. Based on research that has been done on grade IV students of SD 2 Hadipolo, it can

: be concluded that the use of the Contextual Teaching and Learning model can improve students' skills in writing personal opinions.

\section{Abstrak}

Abstrak
Penelitian ini bertujuan untuk meningkatkan kemampuan siswa dalam mengekspresikan pendapat pribadi mereka dengan menggunakan pendekatan model pembelajaran Contextual : Teaching and Learning (CTL). Penelitian ini dilakukan dalam dua siklus dengan 4 pertemuan 35 siswa kelas IV SD 2 Hadipolo dari tahun akademik 2019/2020 dan penelitian ini menggunakan Penelitian Tindakan Kelas. Teknik pengumpulan data melalui pengamatan, pengujian, dan dokumentasi. Hasil studi keterampilan menulis pendapat pribadi menggunakan model pengajaran dan pembelajaran kontekstual menunjukkan bahwa ada peningkatan dalam setiap pertemuan. Keterampilan siswa menulis pendapat pribadi pada pertemuan pertama memperoleh $58 \%$ dan pada pertemuan kedua mencetak $61 \%$ dengan persentase rata-rata $60 \%$ dan cukup berkualitas. Pada pertemuan ketiga mendapat $73 \%$ dan pertemuan keempat mendapat $82 \%$ dengan persentase rata-rata 78\% kualifikasi yang baik. Berdasarkan penelitian yang telah dilakukan siswa kelas IV SD 2 Hadipolo, dapat disimpulkan bahwa penggunaan model Contextual Teaching and Learning dapat meningkatkan kemampuan siswa dalam menulis pendapat pribadi. 


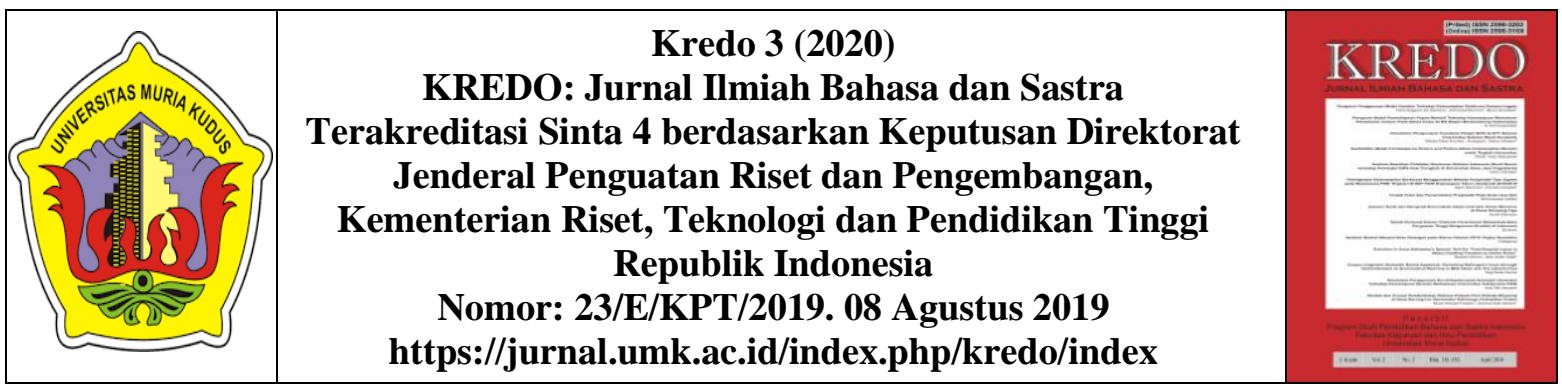

\section{PENDAHULUAN}

Pembelajaran tematik merupakan suatu sistem pembelajaran yang memungkinkan siswa aktif dalam menggali dan menemukan konsep keilmuan yang bermakna (Majid, 2014). Bahasa merupakan pembelajaran yang ada dalam semua jenjang pendidikan. Alat komunikasi yang sering digunakan adalah menggunakan bahasa, penggunaannya bisa melalui kosakata, garakan tubuh seta mimik (Pratiwi, 2019). Sudah diketahui bahwa bahasa merupakan objek untuk berkomunikasi, sehingga biasa dipakai untuk berkomunikasi dan bisa berguna untuk mengemukakan pendapat. Di dunia pendidikan siswa juga dibekali bahasa, mata pelajaran bahasa merupakan pembelajaran yang diarahkan agar siswa dapat meningkatkan keterampilan dalam berkomunikasi baik lisan maupun tulisan.

Pendidikan di Indonesia sekarang ini mengacu pada kurikulum 2013. Semua sekolah mualai dari sekolah dasar hingga sekolah menengah atas diwajibkan untuk menggunakan kurikulum 2013. SD 2 Hadipolo sudah menerapkan kurikulum 2013, dalam penerapan kurikulum 2013 masih terdapat problem dalam pembelajaran. Pembelajaran kurikulum 2013 menekankan siswa untuk lebih aktif dalam pembelajaran, proses pembelajaran yang menerapkan strategi pembelajaran seperti penggunaan model, penggunaan media, dan pengelolaan kelas yang baik akan menciptakan kondisi pembelajaran dan kepribadian siswa yang baik.

Bahasa sebagai alat komunikasi yang amat penting dalam kehidupan, dengan penggunaan bahasa manusia dapat saling berkomunikasi sehingga bisa berbagi informasi dan dapat menambah kemapuan intelektual. Bahasa juga dapat dimanfaatkan untuk berkreasi dan kegiatan yang menunjang kebutuhan. Contoh dari kegiatan yag dapat dilakukan adalah menulis. Kegiatan berkomunikasi siswa dapat dilakukan dengan melalui tulisan sesuai kreasi dan ekspresi dari penulis. Dimyati (2013:207-208) mengemukakan bahwa tujuan aspek keterampilan sebagai adalah kemampuan berkomunikasi, komunikasi non verbal, mengkoordinasikan dengan anggota tubuh, gerakan tubuh.

Keterampilan menulis merupakan suatu keterampilan untuk memberikan pendapat, dan juga suasana denagn tulisan (Sailo, 2017). Kemampuan menulis diperlukan penguasaan berbagai unsur bahasa, agar tulisan yang dihasilkan dapat runtut dan padu. Pembelajaran keterampilan menulis merupakan kegiatan yang harus dapat menghasilkan produktifitas dari siswa. Pengertian menulis merupakan menorehkan ide atau pikiran dalam bentuk tulisan dan dapat dibuat cerita secara tertulis dan dibaca banyak orang. Menulis juga bisa berarti sebuah ungkapan yang dibuat secara tulisan sehingga terjadi komunikasi tidak langsung.

Menulis pendapat pribadi meruapakan bentuk ungkapan atau pandangan dari pemikiran seseorang terhadap suatu kebenaran, dan kebenaran tersebut dipengaruhi dari pendapat atau pandagan pribadi masing-masing yang dapat berpa saran, kritik dan juga penilaian. Dalam berpendapat dapat juga dinamakan dengan opini atau argumentasi. Menulis pendapat pribadi merupakan memberikan pendapat, 


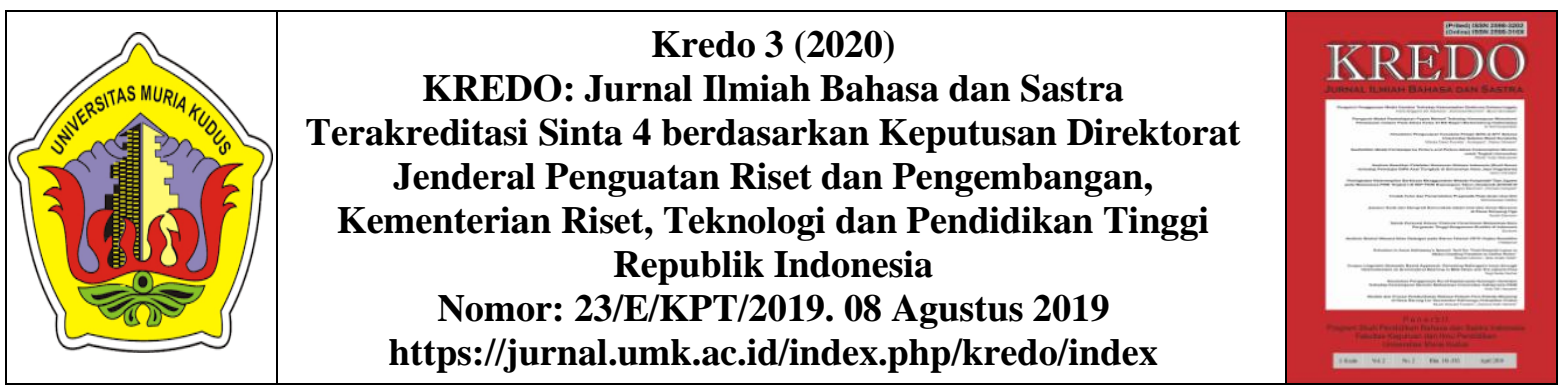

gagasan, opini, atau argumen yang sesuai dengan pimikiran masing-masing dalam bentuk tertulis.

Penyampaian informasi dan suatu ide merupakan suatu kegiatan untuk berkomunikasi, kegiatan tersebut dapat dilakukan dengan cara tertulis atau dengan ucapan. Bentuk penyampaian suatu ide, pendapat dan juga informasi dengan cara tertulis bisa disampaikan berupa karangan, puisi dan lainnya (Nadiya, 2018). Dalam kemampuan menulis dapat mengembangkan daya berfikir kritis dan juga mengungkapkan perasaan, dan menulis menulis merupakan suatu kegiatan yang kreatif karena dalam menulis dapat memilih kosa kata yang tepat sesuai ceritanya (Dibia, 2017)

Berdasarkan observasi pada hari jumat, 2 Agustus 2019 yang dilaksanakan SD 2 Hadipolo dengan siswa-siswa kelas IV, wali kelas sebagai pengajar memberikan pernyataan bahwa siswa dalam keterampilan menulis masih kurang, mulai dari pemilihan kata, penggunaan tanda baca, dan penyusunan kalimat, sehingga hasil dari tulisannnya kurang bisa dimengerti dan bahasa yang digunakan kurang jelas maksud dari tulisannya tersebut. Berdasarkan hasil observasi ditemukan beberapa siswa yang masih kesulitan dalam keterampilan menulis. Guru meminta siswa untuk menuliskan pendapat pribadinya mengenai suatu kejadian pada dirinya, siswa hanya bisa membuat beberapa kata dan siswa merasa kesulitan dalam menemukan kata-kata yang tidak sering mereka pakai, dan siswapun menuliskan dengan bahasa daerah mereka, dikarenkaan dalam penyampaian materi menulis lebih banyak teori yang diberikan dibandingkan praktik. Pada pembelajaran mengemukakan pendapat pribadi guru lebih sering meminta siswa untuk menyampaikannya secara lisan daripada tulisan. Siswa dalam penyampaian pendapat pribadi secara lisan lebih banyak menggunakan bahasa daerah daripada bahasa Indonesia.

Kemampuan menulis bukanlah hal yang mudah, menulis memperlukan minat untuk mengolah kata dan dijadikan suatu karangan yang indah, maka dalam pembelajaran menulis atau mengarang guru harus mempunyai metode atau strategi dalam proses pembelajaran. Strategi pembelajaran sangat diperlukan untuk menciptakan pembelajaran yang kreatif, manarik dan menyenangkan. Siswa dalam pembelajaran menulis beranggapan bahwa menulis bukanlah hal yang menarik tetapi membosankan. Siswa merasa bosan karena siswa kesulitan untuk merangkai kata menjadi kalimat ataupunparagraf secara runtut dan padu (Puspitasari, 2016)

Keberhasilan pembelajaran siswa dipengaruhi oleh peran seorang guru. Usaha untuk dapat menunjang keberhasilan dalam proses pembelajaran adalah dengan memberikan strategi atau pendekatan pembelajaran serta media yang inovatif, menarik dan sesuai dengan pembelajaran yang dipelajarinya. Penggunaan model pembelajaran yang kuang menarik dapat membuat siswa tidak bersemangat dalam mengikuti pembelajaran. Siswa akan merasa bosan dan tidak termotivasi jika dalam pembelajaran yang dilakukan masih dengan metode ceramah. Penggunaan metode ceramah mengakibatkan siswa kurang aktif dan siswa tidak dapat berkreasi dengan apa yang mereka pikirkan. 


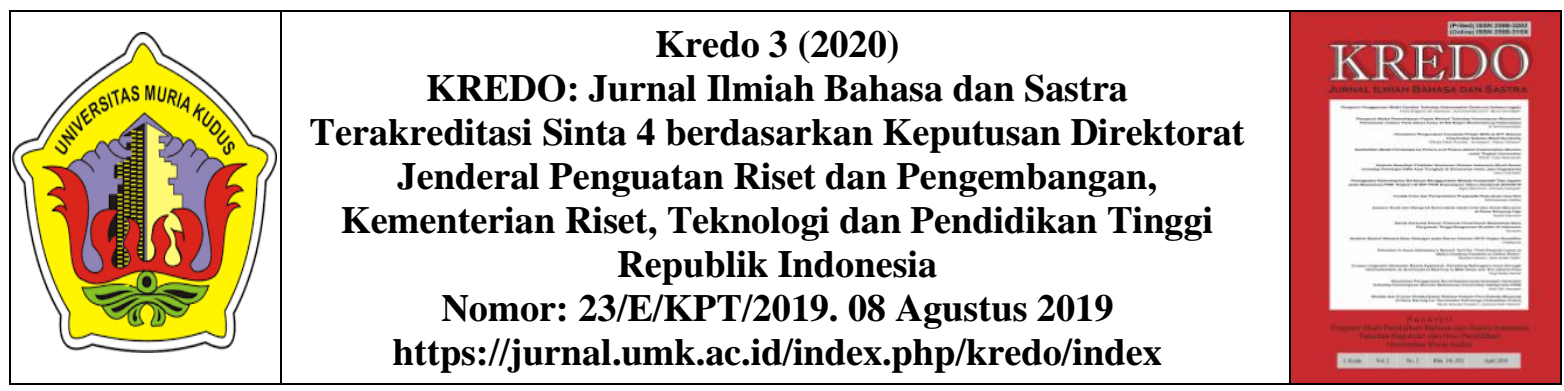

Belajar yang berlandasan masalah merupakan suatu interaksi yang baik sehingga menghasilkan respon yang baik pula, hubungan belajar antara lingkungan dan kondisi siswa. Lingkungan dalam belajar memberi peran untuk menyederhanakan masalah belajar, sedangkan kondisi siswa yang akan mengolah dari bantuan lingkungan secara efrktif sehingga permasalahan dapat di identifikasi serta dicari solusi pemecahan masalah belajar tersebut. Menurut Ratumanan suatu model pembelajaran yang berlandasan masalah adalah model yag efektif digunakan dalam pembelajaran karena dapat meningkatkan pemikiran siswa menjadi lebih tinggi.

Berdasarkan pemaparan diatas, maka perlu dilaksanakan peningkatan menulis pada siswa melalui pembelajaran dengan menggunakan pendekatan model Contectual Teaching and Learning (CTL). Model Contectual Teaching and Learning (CTL) diharapkan dapat menjadi solusi yang tepat untuk membantu siswa dalam mengaitkan materi pembelajaran dengan kehidupan sehari-hari atau lingkungan sekitar dan dapat memotivasi siswa untuk menambah pengetahuannya. Peneliti ingin memperbaiki pembelajaran menulis pendapat pribadi dengan menggunakan pendekatan pembelajaran model Contectual Teaching and Learning (CTL). Hal tersebut supaya anak dapat mengekpresikan pengetahuannya sesuai dengan kehidupan nyata.

Kondisi tersebut relevan dengan penelitian yang dilaksanakan Leksair Markus Alexander yang berjudul "Keterampilan Menulis Teks Narasi Melalui Model Contextual Teaching and Learning". Penelitian yag dilakukan menunjukkan model Contextual Teaching and Learning dapat meningkatkan hasil tes dimana pada pra tindakan jumlah siswa yang tuntas hanya 10 orang atau sebesar $34,48 \%$, pada siklus I jumlah siswa yang tuntas meningkat menjadi 16 siswa atau sebesar $55,17 \%$ dan pada siklus II jumlah siswa yang sudah mencapai nilai 70 juga meningkat menjadi 23 orang atau sebesar 79,31\%. Dengan prsentase ketuntasan siswa sudah mencapi kriteria keberhasilan tindakan yaitu $75 \%$, maka tindakan dikatakan berhasil.

\section{KAJIAN TEORI}

Penelitian ini menggunakan pendekatan model Contectual Teaching and Learning (CTL) dimana model pembelajaran tersebut merupakan strategi pembelajaran yang membantu guru untuk mengaitkan materi pembelajaran dengan kehidupan seharihari ataupun lingkungan sekitar Shoimin (2014:41). Dengan penerapan model Contectual Teaching and Learning (CTL) diharapkan siswa lebih mudah untuk memahami pembelajaran yang dipelajarinya secara alami tanpa harus menghafal. Model pembelajaran yang menyenangkan banyak sekali, salah satunya yaitu Contextual Teaching and Learning yang merupakan model yang mengaitkan materi dengan kehidupan sehari-hari sehingga siswa mudah untuk memahaminya dan siswa tidak jenuh untuk belajar. Mulyasa (2014) menyatakan bahwa model Contextual Teaching and Learning sebagai acuan pembelajaran, guru dapat menyampaikan materi pembelajaran dengan gambaran kondisi nyata yang ada di lingkungan sekitar. Contextual Teaching and Learning merupakan pembelajaran yang 


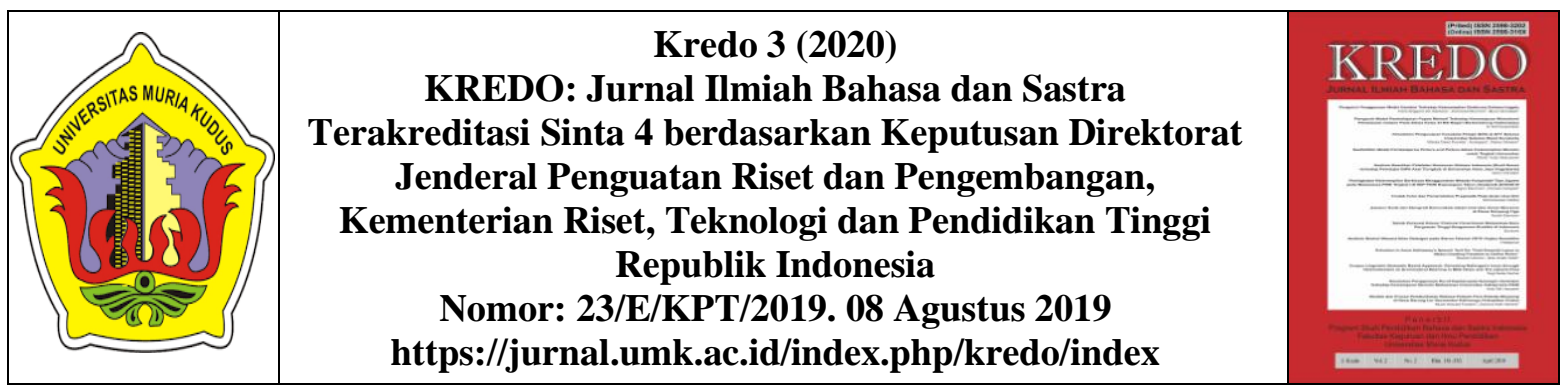

mengedepankan terciptanya lingkungan belajar yang mengaitakn kehidupan sehari-hari. Dalam pendekatan model Contextual Teaching and Learning guru memberikan kondisi pembelajaran yang nyaman agar siswa natusias untuk dapat memahami dan dapat meningkatkan hasil belajar.

\section{METODE PENELITIAN}

Penelitian ini menggunakan Penelitian Tindakan Kelas (PTK) yang dilaksanakan di SD 2 Hadipolo yang terletak di Desa Hadipolo, Kecamatan Jekulo, Kabupaten Kudus. Penelitian ini dilaksanakan pada semester I tahun pelajaran 2019/2020 pada bulan November 2019 dan Subjek penelitian ini adalah siswa kelas IV SD 2 Hadipolo dengan jumlah siswa sebanyak 35 siswa yang terdiri dari 19 siswa putri dan 16 siswa putra. Penelitian ini menggunakan variabel terikat berupa keterampilan menulis siswa, dan variabel bebasnya menerapkan model pembelajaran Contextual Teaching and Learning (CTL). Teknik pengumpulan data dengan teknik tes, teknik nontes, dokuemntasi dan wawancara. Sugiyono (2010: 333) menyatakan analisis data merupakan proses dalam menyususn data secara sistematis yang diperoleh dari hasil wawancara, catatan dan dokumentsi denagn cara mengorganiasikan data ke dalam bentuk kalimat dan menjabarkan unit-unit, menyusun ke dalam pola, memilih mana yang penting untuk dipelajari. Serta membuat kesimpulan sehingga mudah dipahami oleh diri sendiri maupun orang lain. Penelitian ini dilaksanakan dalam dua siklus dan diamana setiap siklus mempunyai tahapan (1) perencanaan (2) pelaksanaan (3) observasi (4) refleksi.

\section{HASIL DAN PEMBAHASAN}

Menulis merupakan bagian terpenting dalam dunia pendidikan, menulis menjadi faktor utama dalam keberhasilan siswa untuk meningkatkan hasil belajar. Keterampilan menulis adalah salah satu manifestasi penggunaan bahasa yang harus dikuasai dalam pembelajaran setelah keterampilan berbicara, membaca dan menyimak. Keterampilan menulis untuk anak sekolah dasar sangat diperlukan untuk menunjang pembelajaran yang di pelajarinya, karena dengan keterampilan menulis yang siswa miliki dapat membantu penggunaan bahasa dan meningkatkan kreativitas siswa. Trianto (2009:45) mengemukakan bahwa pembelajaran menulis merupakan hal yang mendasar dalam proses pembelajaran dan meningkatkan kreativitas siswa. Dibia (2017) keterampilan menulis yang dimiliki siswa dapat menunjang aktivitas dalam pembelajaran menulis sehingga siswa dapat menyeimbangkan dengan keterampilan membaca dan menyimak. Berdasarkan pendapat ahli diatas keterampilan menulis diperlukan untuk anak sekolah dasar dalam pembelajaran, karena keterampilan menulis merupakan suatu sarana untuk meningkatkan aktivitas siswa, dan mampu mengembangkan pemikiran yang kritis dan mengungkapkan pikiran siswa sendiri.

Menulis pendapat pribadi meruapakan bentuk ungkapan atau pandangan dari pemikiran seseorang terhadap suatu kebenaran, dan kebenaran tersebut dipengaruhi dari pendapat atau pandagan pribadi masing-masing yang dapat berpa saran, kritik dan juga penilaian. Dalam berpendapat dapat juga 


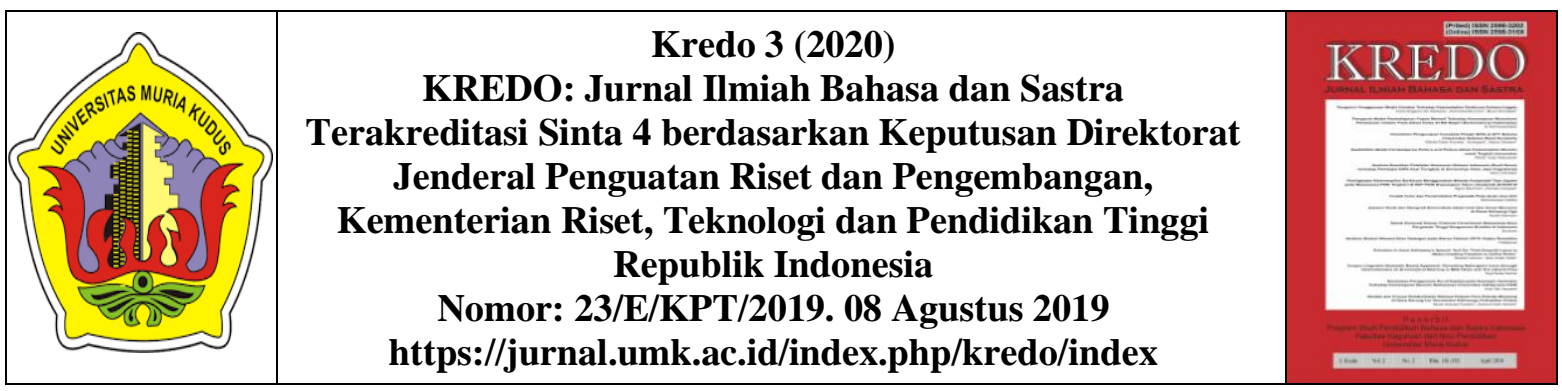

dinamakan dengan opini atau argumentasi. Menulis pendapat pribadi merupakan memberikan pendapat, gagasan, opini, atau argumen yang sesuai dengan pimikiran masing-masing dalam bentuk tertulis.

Hasil wawancara yang sudah dilakukan dengan guru kelas, diketahui bahwa terdapat permasalahan mengenai rendahnya keterampilan siswa dalam menulis. Dalam pembelajaran menulis, minat siswa untuk mengikutinya masih kurang, serta siswa masih bingung untuk penggunaan kata serta pengungkapan ide untuk menulis. Hal ini terlihat pada hasil tes awal yang masih rendah, dengan siswa sebanyak 35 siswa memperoleh rata-rata kelas sebesar $52 \%$ dengan kualifikasi cukup. Berdasarkan hasil keterampilan menulis pendapat pribadi pada tes awal, peneliti memberi solusi untuk meningkatkan keterampilan menulis siswa dengan menggunakan model pembelajaran Contextual Teaching and Learning (CTL). Model pembelajaran Contextual Teaching and Learning merupakan suatu pembelajaran yang efektif digunakan dalam pembelajaran. Model Contextual Teaching and Learning memusatkan pembelajaran pada siswa sehingga membangkitkan partisipasi siswa dalam pembelajaran, model ini mengaitkan materi pembelajaran dengan kehidupan sehari-hari sehingga siswa mudah untuk menggali pengetahuannya sendiri. Lestari (2009:64) berpendapat bahwa Contextual Teaching and Learning merupakan salah satu model pembelajaran kooperatif yang dirancang untuk membuat siswa mampu menghubungkan dari subjek-subjek akademik dengan konteks kehidupan keseharian mereka untuk menemukan makna. Model pembelajaran ini memberikan kesempatan kepada siswa untuk terlibat aktif dalam pembelajaran. Model ini mengedepankan keseharian, pengalaman baru yang merangsang otak, dan membuat hubungan-hubungan baru yang dapat dilibatkan dalam pembelajaran.

Model Contextual Teaching and Learning memiliki kelebihan dan kelemahan dalam pembelajarannya. Shoimin (2014) menyebutkan beberapa kelebihan dalam penerapan model pembelajaran Contextual Teaching and Learning sebagai berikut: 1)Pembelajaran kontekstual dapat menekankan aktivitas berfikir siswa secara penuh, baik fisik maupun mental. 2) Pembelajaran konstektual dapat menjadikan siswa belajar bukan menghafal, melainkan proses berpengalaman dalam kehidupan nyata. 3) Kelas dalam konstektual bukan sebagai tempat memperoleh informasi, melainkan sebagai tempat untuk menguji data hasil temuan lapangan. 4) Materi pembelajaran ditentukan oleh siswa sendiri, bukan hasil temuan orang lain.

Sedangkan kekurangan dalam model Contextual Teaching Learning adalah sebagai berikut (Shoimin, 2014: 55): 1) Penerapan pembelajaran kontektual merupakan pembelajaran yang kompleks dan sulit dilaksanakan dalam konteks pembelajaran, selain itu juga membutuhkan waktu yang lama.

Penelitian ini dilakukan dalam 2 siklus. Setiap siklus dilaksanakan 2 kali pertemuan. Pertemuan pertama memberikan pengertian mengenai pengungkapan pendapat pribadi dan mengungkapkan secara tulisan. Pertemuan selanjutnya pelaksanaan pembelajaran menuliskan pendapat pribadi. Hasil pembelajaran menulis pendapat pribadi pada siklus I 


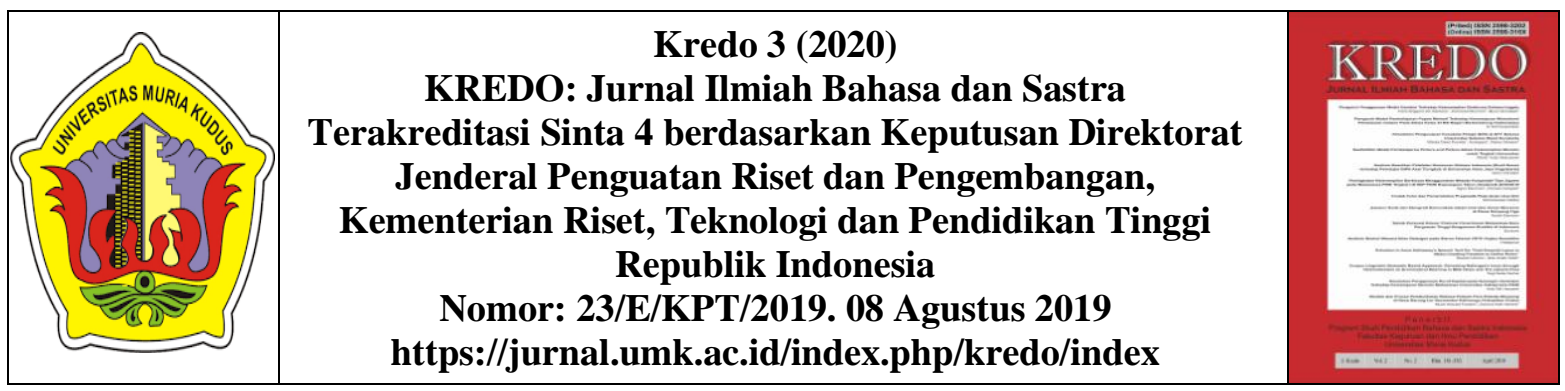

menjukkan adanya peningkatan. Siklus I menulis pendapat pribadi memperoleh rata-rata $60 \%$ dengan kualifikasi cukup. Pembelajaran siklus I menuliskan pendapat pribadi dengan menggunakan model Contextual Teahing and Learning masih terdapat kendala sehingga pembelajaran belum terlaksana dengan maksimal. Pada siklus I siswa masih kesulitan dengan penggunaan kosakata dan alur ceritanya. Hasil tes siklus I keterampilan siswa dalam menulis pendapat pribadi dapat dilihat pada tabel dibawah ini.

Tabel 1. Hasil Keterampilan Menulis Pendapat Pribadi Siklus I

\begin{tabular}{cccc}
\hline & Siklus I & & $\begin{array}{c}\text { Rata- } \\
\text { Rata }\end{array}$ \\
\cline { 1 - 3 } Persentase & Peremuan I & Pertemuan II & $60 \%$ \\
\cline { 1 - 2 } Kualifikasi & Cukup & $61 \%$ & $60 \%$ \\
& & Baik & Cukup
\end{tabular}

Tabel diatas menunjukakan peningkatan keterampialn menulis pendapat pribadi dengan pemggunaan model pembelajaran Contextual Teahing and Learning pada pertemuan I dan pertemian II siklus I.

Penelitian pada siklus I keterampilan menulis pendapat pribadi mengalami peningkatan pada setiap pertemuan, siklus I pertemuan I siswa mengalami kesulitan dalam menemukan kata yang tepat untuk dijadikan kalimat pendapat mereka dan siswa kesulitan dalam mengaplikasikan alur ceritanya. Hal tersebut menjadikan pertemuan I kurang maksimal dalam pembelajaran menulis pendapat pribadi. Pada pertemuan II guru memberikan inovasi pembelajaran dan mangatur strategi agar pembelajaran dapat maksimal. Pertemuan II siklus I siswa sudah dapat menyusun kalimat dengan kata-kata yang baik, dan siswa semangat dalam pembelajaran menulis. Atikah (2017) Dalam menyusun dan merancang pembelajaran memperhatikan penggunaan metode yang sesuai dengan materi yang diajarkan agar pembelajaran dapat tercapai.

Berdasarkan penelitian pada siklus I terdapat beberapa kendala yang dialami siswa yaitu siswa sulit menemukan kata yang tepat untuk dijadikan kalimat, siswa masih sedikit yang menggunakan kata baku, dan siswa masih rendah dalam penggunaan tanda baca. Kunandar (2015: 259) mengemukakan kemampuan melakukan kegiatan sederhana dan sama persis dengan yang dilihat atau diperhatikan sebelumnya. Yustika (2019) untuk memproses dan mengeolah belajarnya secara efektif siswa dituntut aktif secara fisik, intelektual, dan emosiaonal. Pembelajaran pada siklus I terdapat kelemahan. Maka dari itu perlu adanya tindak lanjut dengan lebih mengoptimalkan dan memperbaiki kekurangan-kekurangan dalam pembelajaran. Shoimin (2014: 42) mengemukakan dalam model Contextual Teaching and Learning guru harus mendorong siswa untuk dapat mengaitkan pembelajaran dengan kehidupan sehari-hari. Oleh karena itu peneliti merencanakan perbaikan pembelajaran pada siklus II, dengan memberikan perhatian yang lebih terhadap semua siswa, selain itu penggunaan media lebih ditonjolkan untuk menambah motivasi siswa. Trianto (2011: 75) mengemukakan penggunaan media dan bahan ajar dimaksudkan agar anak dapat bereksplorasi dengan bendabenda dilingkungan sekitarnya. Untuk itu guru memperbaiki proses pembelajaran pada siklus II dengan guru memberikan contoh penggunaan bahasa yang tepat, guru memberikan inovasi 


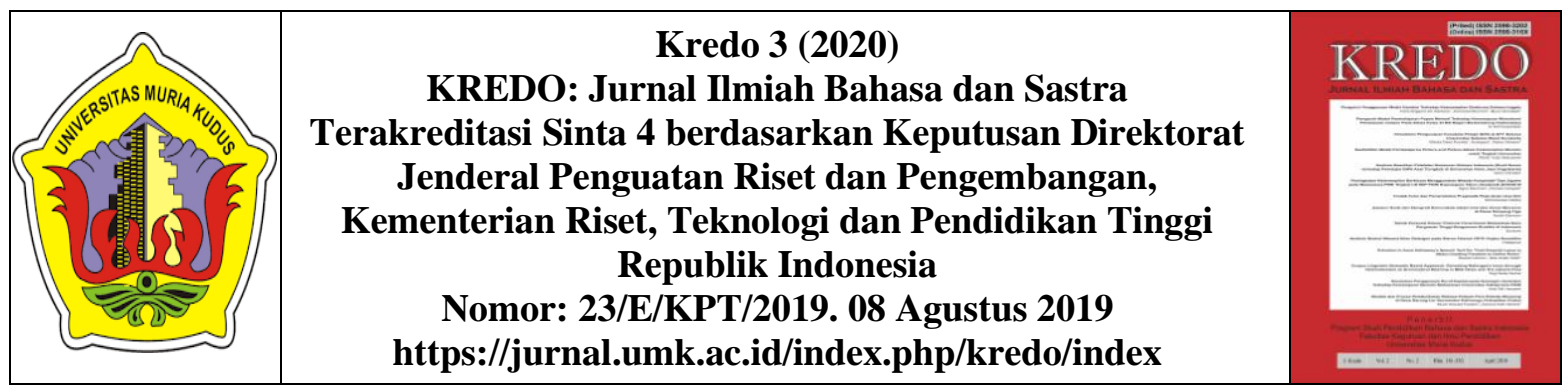

dalam pembelajaran, dan guru memperhatikan siswa yang dirasa kurang bisa menuliskan pendapat pribadinya.

Pelaksanaan pembelajaran di siklus II selama 2 pertemuan, hasil siklus II menunjukkan peningkatan pada pembelajaran. Hasil pembelajarn pada siklus II memperoleh $73 \%$ dengan kualifikasi baik, dan pada pertemuan II memperoleh $82 \%$ dengan kualifikasi baik, rata-rata dari keterampilan menulis pendapat pribadi siswa memperoleh sebesar $78 \%$ dengan kualifikasi baik. Pada sikus II terjadi peingkatan yang baik, dan pada siklus II ini tidak ditemukan banyak kendala, siswa sudah dapat menuliskan pendapat pribadi dengan kosakata yang cukup baik dan penyusunan kalimat yang mudah dimengerti. Hasil keterampilan siswa dalam menulis pendpat pribadi pada siklus II sebagai berikut.

Tabel 1. Hasil Keterampilan Menulis Pendapat Pribadi siklus II

\begin{tabular}{cccc}
\multicolumn{4}{c}{ Pribadi siklus II } \\
\hline \\
Seremuan I & $\begin{array}{c}\text { Pertemuan } \\
\text { II }\end{array}$ & $\begin{array}{c}\text { Rata- } \\
\text { Rata }\end{array}$ \\
\hline & & $82 \%$ & $78 \%$ \\
\hline Persentase & $73 \%$ & Baik & Baik
\end{tabular}

\begin{tabular}{clr}
\hline Tabel diatas menunjukkan \\
peningkatan & keterampilan menulis
\end{tabular}
pendapat pribadi dengan pemggunaan model pembelajaran Contextual Teahing and Learning pada pertemuan I dan pertemian II siklus II.

Peneliti telah melaksanakan penelitian keterampilan siswa siklus I dan siklus II . Dan peneliti akan menyajikan diagram persentase aspek keterampilan siswa kelas IV SD 2 Hadipolo siklus I dan siklus II sebagai berikut.

256 | Jurnal Kredo Vol. 3 No. 2 April 2020

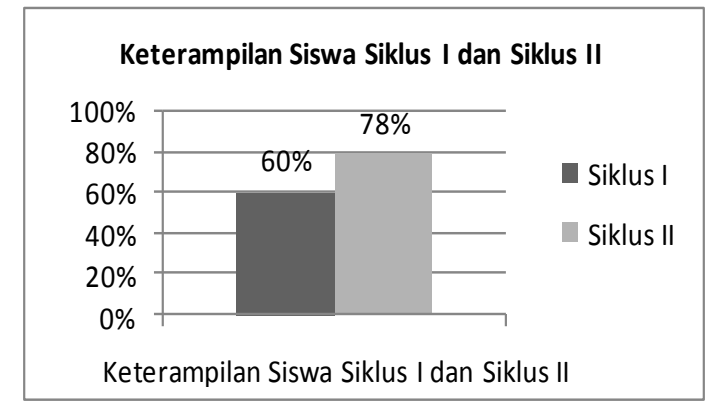

Gambar I. Persentase Keterampilan Siswa Siklus I dan Siklus

Berdasarkan gambar I diatas dapat disimpulkan bahwa dengan menggunakan model pembelajaran Contextual Teaching and Learning dapat meningkatkan hasil keterampilan menulis pendapat pribadi siswa secara individu maupun klasikal. Pada siklus I mendapat $60 \%$ dan pada siklus II mendapat $78 \%$.

Pelaksanaan kegiatan penelitian tindakan kelas peneliti dalam memperbaiki proses pembelajaran dengan menerapkan model pembelajaran Contextual Teaching and Learning sudah dilaksanakan dengan baikdan lancar. Proses pembelajaran yang dilaksanakan sudah terpusat pada siswa dan pembelajaran sudah sesuai dengan alokasi yang telah direncanakan, namun masih terdapat beberapa siswa yang belum berhasil dalam proses pembelajaran. Berdasarkan pengamatan dapat disimpulkan bahwa dalam penelitian aspek keterampilan siswa penerapan model pembelajaran Contextual Teaching and Learning dalam menulis pendapat pribadi kelas IV SD 2 Hadipolo hasil belajarnya meningkat sehingga peneliti tidak melanjutkan penelitian pada siklus selanjutnya.

Proses pembelajaran keterampilan bertanya mengenai matari yang telah dipelajari. Pada pertemuan I siklus I 


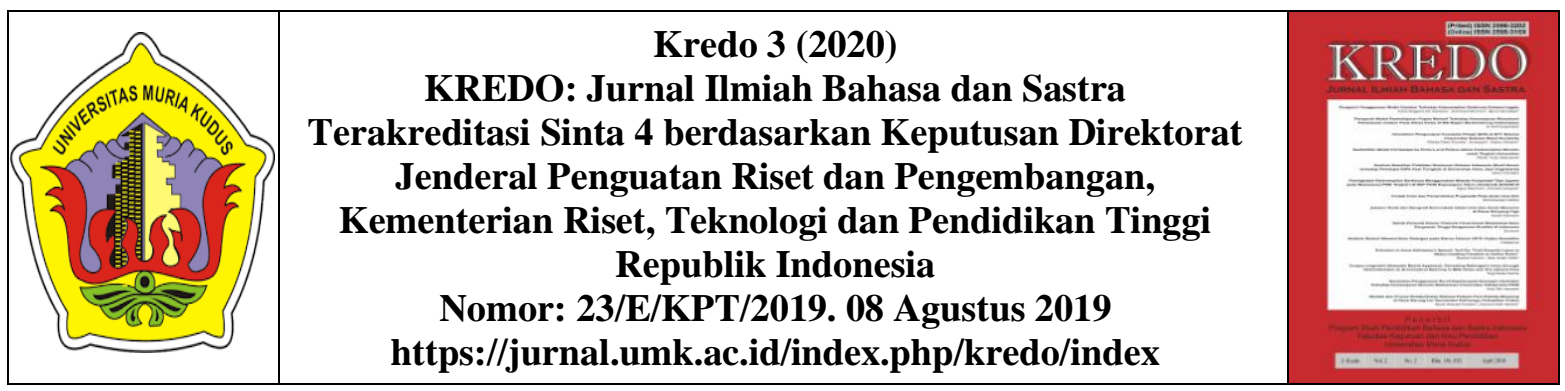

siswa masih pasif untuk bertanya kepada guru dan pada siklus II guru memperbaiki pembelajaran agar terdapat perubahan, sehingga pada siklus II terdapat siswa bertanya dan guru merespon pertanyaan. Siswa memerlukan waktu berpikir untuk dapat menjawab dengan tepat pertanyaan dari guru, dan guru juga dituntut untuk memberikan pembelajaran yang menyenangkan supaya tercipta proses pembelajaran yang berkualitas. Sama halnya yang dikatakan Sanjaya (2012: 34) bahwa dalam setiap proses pembelajaran bertanya merupakan kegiatan yang selalu bagian yang tidak dapat dipisahkan terhadap pembelajaran.

Keterampialan mengadakan variasi yang mana guru memberikan variasi pada pembelajarannya dengan menggunakan model pembelajaran Contextual Teaching and Learning. Guru memberikan penjelasan mengenai materi dengan tujuan yang akan dicapai pada pembelajaran siklus I dan siklus II. Pada siklus I di pertemuan I dan II guru masih kesulitan untuk dapat menumbuhkan antusias siswa dalam pembelajaran karena siswa kurang aktif. Kurang aktifnya siswa dapat diakibatkan karena kurangnya interaksi guru terhadap siswa. Dengan hal demikian guru memperbaiki pada pertemuan selanjutnya dengan membangun interaksi dengan siswa sebaik mungkin. Berdasarkan Majid (2014: 224) mengemukakan proses pembelajaran akan berhasil secara efektif jika terjadi interaksi langsung antara pendidik dengan peserta didik.

Keterampilan menjelaskan, pada keterampilan menjelaskan dipertemuan I siklus I guru masih belum maksimal dalam menjelaskan materi sehingga ada siswa yang belum dapat memahami.
Pada pertemuan selanjutnya guru meningkatkan penjelasan materi secara maksimal agar siswa mudah untuk mengerti. Pada penjelasan materi di pertemuan selanjutnya guru sudah runtut dan mengaitkan meteri pembelajaran dengan pengetahuan yang dimiliki siswa, sehingga siswa mudah untuk memahami. Surya (2016: 54) mengaktifkan pengetahuan yang telah dimiliki siswa, informasi harus disajikan dan dikerjakan melalui cara-cara yang mencerminkan bagaimana siswa akan diminta untuk menggunakan informasi dalam kehidupan sehari-hari.

Indikator pengetahuan kedua mengenai memahami, pada pembelajaran yang berlangsung pada siklus I siswa masih bingung menganai pekerjaan yang terdapat dilingkungan sekitar dan siswa belum dapat memberikan pemaparan konsep pembelajaran. Dan pada tahap II guru memberikan sedikit pandangan mengenai materi yang diajarkan dan siswa menjadi lebih mudah memahami dan pembelajaran berjalan dengan baik serta penggunaan media untuk merangsa siswa menemukan konsep pembelajaran. Jamaris (2014: 93) kesulitan berfikir merupakan hasil dari kesulitan anak dalam melakukan operasi kognitif dan adaptasi fungsional. Mawaddah (2016) Pengetahuan baru akan lebih melekat lebih lama apabila siswa dilibatkan secara langsung dalam proses pemahaman dan mengintruksi sendiri konsep dan pengetahuan.

Indikator keterampilan menulis dengan menggunakan kata baku, siswa dalam memilih kata untuk menuliskan pendapat pribadi pertemuan I siklus I masih kesulitan dan menggunakan bahasa daerah untuk menyampaikan pendapatnya melalui tulisan. Terdapat 


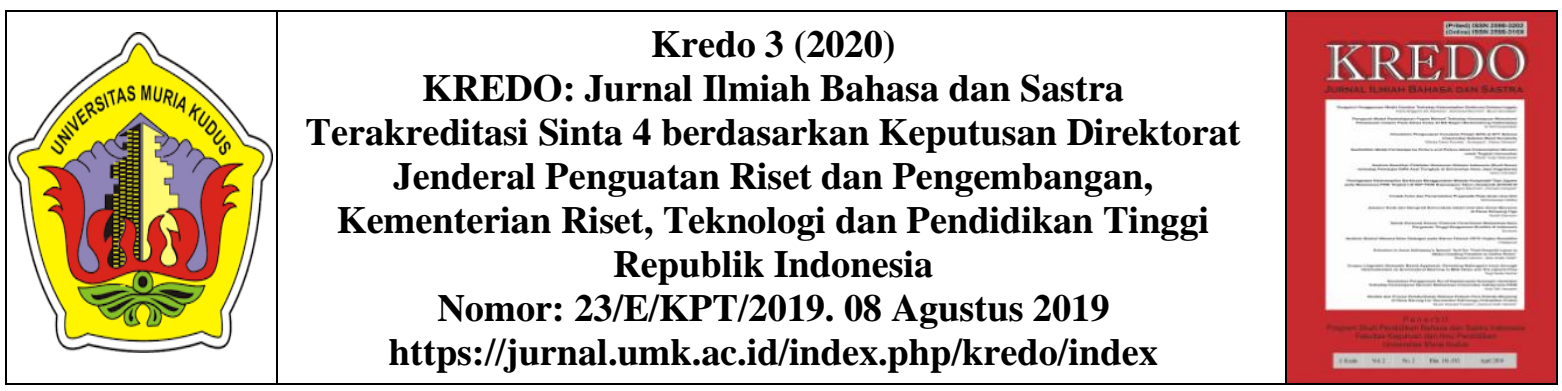

salah satu siswa mengungkapkan pendapat pribadinya dengan bahasa keseharian dalam tulisannya. Guru memberikan bantuan dalam pembelajaran untuk menyusun pendapat pribadi siswa dengan menggunakan kata-kata baku. Pertemuan selanjutnya siswa berusaha sendiri menyusun pendapat pribadi menggunakan kata baku.

Indikator keterampilan menulis menggunakan kalimat yang mudah dipahami, siswa menuliskan pendapat pribadi masih belum bisa dipahami pada setiap kalimatnya, siswa masih bingung untuk menceritakan pendapat mereka menggunakan tulisan. Kalimat yang dituliskan masih di ulang-ulang pada kalimat selanjutnya sehingga pembaca maupun pendengar belum bisa menangkap cerita yang dituliskan. Pertemuan selanjutnya guru memberi inovasi dan contoh penggunaan kata menjadi kalimat yang mudah dipahami, dan siswa bisa mengikutinya dengan baik.

Indikator keterampilan menulis dengan menggunakan tanda baca yang baik, dalam penggunaan tanda baca siswa untuk menuliskan pendapat pribadi masih rendah. Terdapat siswa menuliskan pendapat pribadinya tanpa menggunakan tanda baca sama sekali. Rendahnya siswa menggunakan tanda baca yang baik, guru memberi contoh penggunaan tanda baca yang tepat sehingga tulisan mudah untuk dicerna dan dimengerti.

Berdasarkan penjelasan tabel dan grafik diatas, memberikan bukti bahwa penelitian ini berhasil dan berakhir pada siklus II. Penelitian ini jika dikaitkan dengan penelitian yang dilakukan Wibowo yang merupakan penelitian relevan dengan penelitian ini, maka kedua penelitian ini dapat mengatasi problem yang dihadapi dalam penelitian. Jika dalam penelitian ini menggunakan model Contextual Teahing and Learning dapat meningkatkan keterampilan menulis pendapat pribadi, maka penelitian yang dilakukan Wibowo menggunakan model Contextual Teaching and Learning dapat meningkatkan keterampilan menulis deskripsi. Hal tersebut sesuai dengan pendapat Basunari (2017) semakin efektifnya pembelajaran yang dilaksanakan oleh guru, sudah tentu memberikan dampak positif terhadap motivasi belajar siswa. Diharapkan penerapan model pembelajaran dapat meningkatkan minat siswa dalam belajar dan siswa dapat meningkatkan hasil belajarnya. Menurut Majid (2014:180) menagitakan materi yang diajarkan dengan situasi sunia nyata siswa dan mendorong membuat hubungan antara pengetahuan yang dimilikinya dangan penerapan dalam kehidupan mereka sebagai anggota keluarga dan masyarakat.

Pada pelaksanaan penelitian yang telah dilakukan mengenai menuliskan pendapat pribadi menggunakan model pembelajaran Contextual Teaching and Learning terdapat kelebihan dan kekurangan selama pembelajaran berlangsung. Kekurangan dalam pembelajaran yang telah dilaksanakan mulai dari siklus I adalah kurangnya aktivitas siswa dalam bertanya penggunaan kosa kata yang tepat untuk menyusun kalimat pendapatnya agar mudah untuk dibaca dan dimengerti banyak orang sehingga kalimat yang dihasilkan kurang dimengerti. Siklus II memberikan sebuah inovasi dalam pembelajaran untuk memperbaiki pembelajaran pada siklus I yang masih 


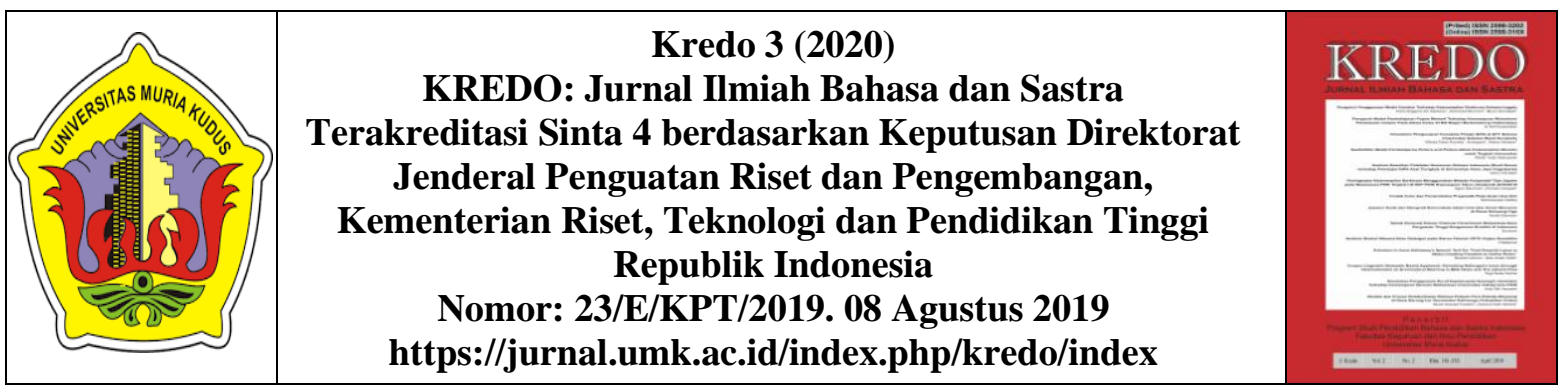

banyak pembenahan pembelajaran maka guru meminta siswa untuk bertanya baik kepada teman sebaya atau kepada guru, dan guru berkeliling memeriksa menanya kepada siswa da memberi batuan jika siswa kurang mengerti dan masih dirasa bingung. Penggunaan model Contextual Teaching and Learning memberikan bantuan dalam pembelajaran karena sistem model pembelajaran ini mengedepankan mengaitkan pembelajaran dengan kehidupan sehari-hari. Kelebihan penelitian yang dilakukan adalah siswa dapat menyampaikan pendapat mereka dengan sesuai realita yang mereka ketahui dalam bentuk tulisan. Model Contextual Teaching and Learning sebagai inovasi pembelajaran yang menekankan siswa untuk dapat lebih aktif mencari materi pembelajaran sendiri tanpa harus menunggu guru. Didalam pembelajaran penelitian ini siswa sangat antusias dalam mencari kosa kata yang baik dan sesuai dengan kalimat yang akan di ungkapkannya dalam bentuk tulisan. Penelitian ini memberikan inovasi yang baru kepada siswa dalam pembelajaran dan siswa merasa terbantu dan semangat dalam pembelajaran. Pada siklus II aspek keterampilan siswa menggalami peningkaatan dengan batas minimal yang ditentukan yaitu $75 \%$. Persentase klasikal pada siklus II sebesar $78 \%$. Dapat disimpulkan untuk aspek keterampilan siswa siklus I ke siklus II sudah mencapai batas aspek keterampilan yaitu $75 \%$.

Hasil penelitian ini juga dapat diperkuat oleh penelitian yang dilakukan oleh Maghfiroh (2014) menyatakan bahwa aspek ketrampilan menulis pada siklus I persentase klasikal mencapai $71 \%$ dan pada siklus II persentase klasikal mencapai 91,11\%. Dari hasil tersebut dapat disimpulkan bahwa dengan indikator aspek keterampilan menulis siswa yang telah ditentukan batas minimalnya, siswa terlihat aktif dalam mengikuti pembelajaran. Gunawan (2013: 106) Siswa dituntut untuk mengenal dengan baik permasalahan tersebut dan memilih prosedur yang tepat untuk menyelesaikan permasalahan. Yudhi (2017) Siswa mengontruksi pemahamannya sendiri-sendiri, pengetahuan baru dibangun berdasarkan pengetahuan dan pengetahuan sebelumnya.

Berdasarkan pembahasan diatas dapat disimpulkan bahwa pada siklus II hasil belajar siswa aspek pengetahuan mengalami peningkatan dibandingkan prasiklus dan juga siklus I. Sanjaya (2012:44) kondisi belajar yang optimal berhubungan dengan kemampuan guru dalam mengambil inisiatif dalam mengendalikan kegiatan belajar mengajar agar berada dalam kondisi yang kondusif sehingga perhatian siswa terpusat pada materi pelajaran. Basunari (2017) semakin efektifnya pembelajaran yang dlaksanakan oleh guru, sudah tentu memberikan dampak positif terhadap motivasi belajar siswa.

Gejala yang dialami siswa dapat disikapi baik oleh guru. Guru dapat memberikan kesempatan pada siswa untuk terlibat aktif dalam pembelajaran. Hal tersebut sesuai pendapat Hamdayana (2015: 31) mengemukakan bahwa dalam pembelajaran siswa ikut terlibat dalam mencari infomasi, dan melakukan penyidikan serta mengajukan pertanyaan. Bahwa hal tersebut menunjukkan dengan penerapan model Contextual Teaching and Learning kelas IV Sd 2 Hadipolo mampu meningkatkan 


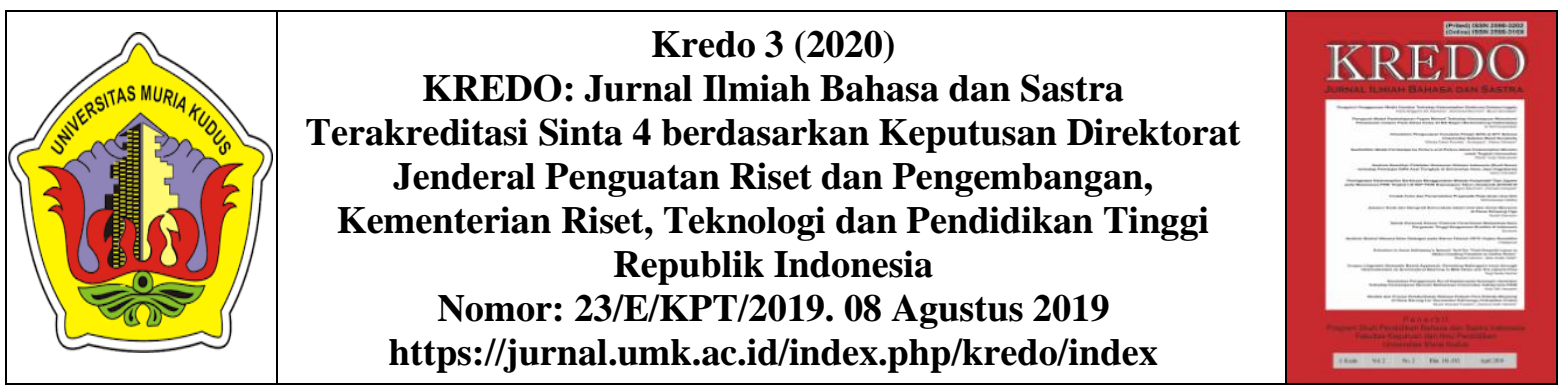

keterampilan menulis siswa aspek pengetahuan. Surya (2016: 54) mengaktifkan pengetahuan yang telah dimiliki siswa, informasi harus disajikan dan dikerjakan melalui cara-cara yang mencerminkan bagaimana siswa akan diminta untuk menggunakan informasi dalam kehidupan sehari-hari.

Berdasarkan pembahasan diatas penelitian tindakan kelas ini sudah berhasil. Dikatakan sudah berhasil karena hasil yang didapat sudah memenuhi hipotesis yaitu adanya peningkatan dalam keterampilan menulis menggunakan penerapan model Contextual Teaching and Learning SD 2 Hadipolo dan sudah memenuhi ketuntasan klasikal pada aspek keterampilan menulis siswa. Berdasarkan pemaparan diatas dapat disimpulkan bahawa hipotesis tindakan yang diambil dapat diterima dan teruji kebenarannya. Maka dapat disimpulkan penerapan model Contextual Teaching and Learning dapat meningkatkan keterampilan menulis pendapat siswa kelas IV SD 2 Hadipolo.

\section{SIMPULAN}

Berdasarkan penelitian hasil belajar aspek pengetahuan dan keterampilan siswa terdapat peningkatan dengan menerapkan model pembelajaran Contextual Teaching and Learning siswa kelas IV SD 2 Hadipolo Pelaksanaan penelitian ini di awali dengan tindakan prasiklus, diamana pada kegiatan prasiklus siswa masih pasif dalam proses pembelajaran dan keterampilan menulisnya masih rendah. Pada pembelajaran siklus I beberapa siswa sudah mengikuti pembelajaran dengan baik dan ada juga siswa yang masih bermain sendiri. Kondisi yang seperti ini lebih baik daripada pratindakan dibuktikan dengan keaktifan siswa untuk bertanya dan keterampilan siswa semakin membaik. Pada siklus II keterampilan siswa dalam menuliskan pendapat pribadinya mengalami peningkatan. Berdasarkan data keterampilan menulis siswa pratindakan sebesar 52\% berkualifikasi cukup, untuk siklus I mendapatkan $60 \%$ dengan kualifikasi cukup. Serta pada siklus II meningkat menjadi $78 \%$ dengan kualifikasi baik. Dengan hasil tersebut, penggunaan metode pembelajaran Contextual Teaching and Learning bisa meningkatkan keterampilan menulis pendapat pribadi siswa kelas IV SDN 2 Hadipolo. Dengan demikian secara klasikal pembelajaran keterampilan menulis pendapat pribadi telah mencapai ketuntasan yaitu $70 \%$.

Penerapan model pembelajaran yang dilaksanakan oleh guru, diharapkan siswa dapat mengkuti pembelajaran yang di ajarkan menggunakan berbagai model pembelajaran, dan pada proses pembelajaran sebaiknya siswa memperhatikan guru dan tidak main ataupun berbicara sendiri dengan teman yang lain, sehingga tercipta suasana proses pembelajaran menjadi kondusif. Dan apa yang telah dijelaskan oleh guru siswa mampu memahami dengan baik dan mendapatkan hasil yang baik. Guru dalam melaksanakan pembelajaran hendaknya memberikan pembelajaran yang bervariatif agar siswa tidak merasa bosan dengan materi yang diajarkan dan guru mengoptimalkan proses pembelajaran yang berlangsung dengan menerapkan berbagai model pembelajaran sehingga menumbuhkan rasa semangat siswa untuk belajar. 

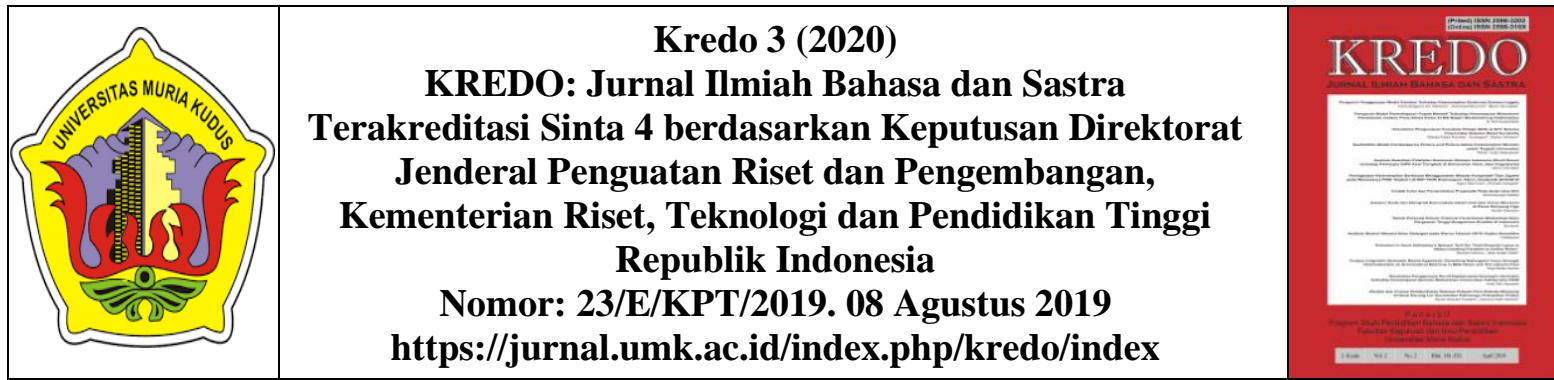

DAFTAR PUSTAKA

Atiah,dkk. 2017. Penerapan Metode Survey, Question, Read, Recite, Review(SQ3R) Dengan Permainan "Pos Pelangi" Untuk Meningkatkan Kemampuan Menyimpulkan Isi cerita Anak yang Dibaca. Jurnal Pena Ilmiah. Vol 2 Nomer 1.

Dibia, I Ketut. 2017. Pemberdayaan Teknik Bercerita Berbasis Budaya Bali Dalam Pembelajaran Keterampialn Menulis Karangan Pribadi Siswa Kelas V SD Mutiara Singaraja. Journal Of Research and Evaluation.1, 2, 113-119.

Dimyati dan Mudjiono. 2013. Belajar dan Pembelajaran. Jakarta: PT Rineka Cipta.

Jamaris, Martini. 2014. Kesulitan Belajar Perspektif, Asesmen, dan penanggulannya. Bogor: Ghalia Indonesia.

Majid, Abdul. 2014. Pembelajaran Tematik Terpadu. Bandung. PT Remaja Rosdakarya offset.

Nadya, Ifrohatun. 2018. Pembelajaran CTL (Contextual Teahing and Learning ) Untuk Meningkatkan Keterampilan Membaca Dan Menulis Siswa Kelas II SD Sumari. JTIEE. 2, 2, 94-104.

Panjaitan. 2018. Peningkatan Pemahaman dan Aplikasi Konsep Melalui Pendekatan Contextual Teaching and Learning. Jurnal MathEducation. Vol.1. No. 52-59.

Pratiwi, Alcheca Dinari. Erna Yayuk. Jani Rima Wijaya. 2019. Keterampilan Menulis Puisi Model CTL Pada Tema 5 Suntema 3 Di Kleas II Sekolah Dasar. 7, 1, 1-6.

Puspita, Sari. Enjang Supriatna. 2016. Model Pembelajaran kontekstual
Berbasis Pengalaman Dalam Pembelajaran Menulis Teks Anekdot Pada Kelas X SMA Negeri Bandung. Jurnal Ilmiah UPT P2M STKIP Siliwangi. 3, 1

Rahmawati, Novie Suci. 2018. Analisis kemampyan komunikasi matematik siswa SMK Pada Materi Sistem Persamaan Linier Dua Variabel (SPLDV). Jurnal On Education. Vol 01 Nomer 02 hal 344-352.

Ratnaningdyah, Dwi. 2017. Penerapan Model Pembelajaran Novick Dipadukan Dengan Strategi Cooperatif Problrm Solving (CPS) Untuk Meningkatkan Kemampuan Pemecahan Masalah Siswa SMA. Jurnal Wahana Pendidikan Fisika. Vol 2 Nomer 2 hal 56-67

Rosyida, Ais. 2018. Pengembangan Media Komik Berbasis CTL Untuk Meningkatkan Hasil Belajar Siswa Sekolah Dasar. Jurnal Kajian Pendidikan dan Hasil Penelitian.Vol 4. No 3.

Sailo, Irawati. 2017. Peningkatan Keterampilan Menulis Karangan Narasi Menggunakan Model Contextual Teaching and Learning Siswa Kelas IV. Jurnal Pendidiakn Guru Sekolah Dasar. 5, 501.

Shoimin, Aris. 2014. 68 Model Pembelajaran Inovatif dalam Kurikulum 2013. Jakarta: Ar-Ruzz Media.

Sugiyono. 2010. Metode Penelitian Pendidikan Pendekatan Kuantitatif, Kualitatif, dan $R \& D$. Bandung: Alfabeta.

Wibowo. Kartono. Hidayah. 2014. Penerapan Model Kontekstual (CTL) Untuk Meningkatkan Keterampialn Menulis Diskripsi. 


Kredo 3 (2020)
KREDO: Jurnal Ilmiah Bahasa dan Sastra
Terakreditasi Sinta 4 berdasarkan Keputusan Direktorat
Jenderal Penguatan Riset dan Pengembangan,
Kementerian Riset, Teknologi dan Pendidikan Tinggi
Republik Indonesia
Nomor: 23/E/KPT/2019. 08 Agustus 2019
https://jurnal.umk.ac.id/index.php/kredo/index

Didaktika Dwija Indria. 3,4, 199204.

Yustika, Gebi. 2019. Peningkatan HasilDan Keaktifan Belajar Siswa Melalui NHT. Journal Cendikia. Vol 03 Nomer o2 hal 481-493. 